ZOOLOGIA 30 (6): 692-696, December, 2013

http://dx.doi.org/10.1590/S1984-46702013005000011

\title{
New species and new records of Notonecta (Hemiptera: Heteroptera: Notonectidae) from Brazil
}

\author{
Julianna F. Barbosa ${ }^{1,2} \&$ Jorge L. Nessimian
}

\begin{abstract}
${ }^{1}$ Laboratório de Entomologia, Departamento de Zoologia, Instituto de Biologia, Universidade Federal do Rio de Janeiro. Avenida Carlos Chagas Filho 373, CCS, bloco A, sala 107, Cidade Universitária, Caixa Postal 68044, 21941-971 Rio de Janeiro, RJ, Brazil.

${ }^{2}$ Corresponding author: julianna.freires@gmail.com
\end{abstract}

\begin{abstract}
Notonecta itatiaia sp. nov. is described from the state of Rio de Janeiro. Like other Notonecta species that occurs in Brazil, N. itatiaia has no remarkable diagnostic features than the shape of genital capsule. Along with the first description of a Notonecta from Brazil in eighty years, N. disturbata is newly recorded from the states of Pará, Piauí and São Paulo, and N. pulchra from Pará. A key to species of Notonecta (males) occurring in Brazil is given.
\end{abstract}

KEY WORDS. Atlantic Forest; identification key; Neotropical Region; Notonectinae; taxonomy.

Notonecta Linnaeus, 1758 is a cosmopolitan genus with about 65 species (Truxal 1979), and is one of the four genera of the tribe Notonectini (ŠTYs \& Jansson 1988). Individuals of this genus are mid-sized notonectids, with a maximum body length of $16 \mathrm{~mm}$, being smaller than Enithares Spinola, 1837 and Enitharoides Brooks, 1953. Members of Notonecta have the pronotum with lateral margins not foveate, median femur stout with anteapical pointed protuberance, and genital capsule symmetric. They are found in lentic waters with moderate to high abundance of submerged plants (López Ruf et al. 2003). Some species prefer shady places under bushes whereas others are found on open waters (HUNGERFORD 1933).

According to Moreira et al. (2011), seven species of Notonecta occur in Brazil: N. bifasciata Guérin-Méneville, 1844, N. disturbata Hungerford, 1926, N. polystolisma Fieber, 1851, N. pulchra Hungerford, 1926, N. nigra Fieber, 1851, N. sellata Fieber, 1851 and $N$. variabilis Fieber, 1851 . The last three species have no other records in Brazil since their descriptions. Most of the records of Notonecta from Brazil are restricted to the southeastern region of the country, where three species are more commonly found: $N$. polystolisma, N. disturbata and N. pulchra (Nieser \& Melo 1997, Vianna \& Melo 2003, Souza et al. 2006, Ribeiro et al. 1998, 2010). Since the revision of Notonecta made by Hungerford (1933), no other species of the genus has been described from Brazil. In this work a key to the species that occur in Brazil is provided, including a new species, along with new records from the country.

\section{MATERIAL AND METHODS}

Specimens are deposited in the Coleção Entomológica Prof. José Alfredo Pinheiro Dutra, Departamento de Zoologia, Instituto de Biologia, Universidade Federal do Rio de Janeiro,
Rio de Janeiro (DZRJ) and Instituto Nacional de Pesquisas da Amazônia, Manaus (INPA). In quotations of label data, a comma separates different information and a semicolon separates information of different specimens. An exclamation mark (!) indicates new records of a species. Collectors are cited in parentheses. The full citation of individual specimens collected at the same locality on different dates is not given. The letter " $\mathrm{m}$ " refers to male specimens and the letter " $\mathrm{f}$ " to female ones. All localities are listed geographically from north to south.

Measurements were made with an ocular micrometer on a stereoscopic microscope and are given in millimeters. Morphological terms follow Hungerford (1933). The dissected genital structures are stored in microvials with alcohol. In the absence of $N$. nigra, N. sellata, N. variabilis and N. bifasciata specimens, their illustrations were based on HungERFord (1933).

\section{TAXONOMY}

\section{Key for males of Notonecta occurring in Brazil (modified from HUNGERFORD 1933)}

1. Anterior width of vertex equal to two times synthlipsis width

2

$1^{\prime}$. Anterior width of vertex greater than two times synthlipsis width

3

2. Body length $16 \mathrm{~mm}$. Male genital capsule with a digitiform process (Fig. 1) ......................................................... nigra

2 '. Body length $11 \mathrm{~mm}$. Male genital capsule without digitiform process (Fig. 8) N. itatiaia sp. nov.

3. Clasper apex bifurcate ….................................................. 4

$3^{\prime}$. Clasper apex not bifurcate ............................................ 5 
4. Anterior width of vertex three times synthlipsis width. Base of clasper narrow, widening at apex (Fig. 2) ...... N. sellata

4 '. Anterior width of vertex two and one-half times synthlipsis width. Entire body of clasper with about the same width (Fig. 3) N. variabilis $^{1}$

5a. Anterior width of vertex about four times synthlipsis width. Genital capsule with one caudoventral protuberance (Fig. 4) N. pulchra

5. Anterior width of vertex about three times synthlipsis width. Genital capsule with two caudoventral protuberances .. 6

6. Body length $9 \mathrm{~mm}$ or greater. Base of clasper narrower than the apex, which surpasses the apex of genital capsule (Fig. 5) N. polystolisma

6 '. Body length less than $9 \mathrm{~mm}$. Base of clasper large, tapering along the length, with apex not surpassing the apex of genital capsule

7. Anterior width of vertex a little less than four times synthlipsis width. Genital capsule with dorsal portion pointed; caudoventral protuberances acute and clearly defined (Fig. 6) N. disturbata

7'. Anterior width of vertex a little less than three times synthlipsis width. Genital capsule with dorsal portion rounded; caudoventral protuberances rounded and not clearly defined (Fig. 7) N. bifasciata

\section{Notonecta itatiaia Barbosa \& Nessimian sp. nov. Figs $9-12$}

Material type. Holotype male macropterous, labeled: BR, RJ - Itatiaia [Parque Nacional do Itatiaia, brejo próximo ao córrego das Agulhas Negras, $22^{\circ} 23^{\prime} 05.40^{\prime \prime} \mathrm{S} / 44^{\circ} 40^{\prime} 41.70^{\prime \prime} \mathrm{W}$, 2.397 m], 8.IV.2006 (R.B. Braga; F.F.F. Moreira; A.P.M. Santos; J.L. Nessimian): $1 \mathrm{~m}$ macropterous, holotype (DZRJ).

Description. Measurements. Body length: 10.96; head width: 2.88; vertex length: 1.31 ; vertex width: 1.2 ; synthlipsis: 0.58 ; rear margin of eye: 1.09 ; pronotum length: 2.05 ; pronotum width: 4.03; scutellum length: 3.03 ; scutellum width: 3.32. Color. Head and pronotum yellow dorsally. Labrum yellow bordered with brown. Triangle at apex of second rostral segment stained with brown; third rostral segment yellowish with brown surface; fourth rostral segment dark brown. Propleuron brown. Scutellum dark brown. Metathorax brown. Hemelytra dark brown with claval suture delimited by a yellow stripe, a short yellow stripe below, and a dimmed yellow stain before membrane (Figs 9 and 10). Legs entirely yellow except coxae brown. Dorsal and ventral surface of abdomen brown. Connexivum yellow. Head. Vertex a little longer than its anterior width; slightly longer than rear margin of an eye and more convex than anterior margin of eye. Synthlipsis wide, about one-half of width of anterior margin of vertex and a little longer than one-half rear margin of an eye. Thorax. Pronotum width 1.6 times its longitudinal median length; length about 1.6 times longitudinal length of head; posterior margin straight with oblique extremities anterad. Scutellum distinctly longer than pronotum. Membranal lobes of hemelytra equal. Anterior trochanter with a hook at lateral margin. Mesotrochanter rounded. Apex of metaxyphus V-shaped. Internal margin of hind femur slightly sinuous. Abdomen. Ventral keel not bare. Penultimate abdominal sternite with spatulated apex. Last abdominal sternite deltoid with truncated apex (Fig. 11). Genital capsule without digitate process, with caudoventral and posterior pointed protuberance and dorsal portion acute (Fig. 12). Clasper apex not bifurcate; slightly longer than dorsal portion of genital capsule; two-thirds of clasper length broad from base, tapering at apical third.

Etymology. The species epithet, itatiaia, refers to the locality (municipality of Itatiaia) in which the holotype was collected.

Remarks. In general, the species of Notonecta do not show many diagnostic features. Identification is performed through ratios between measures and by the shape of the genital capsule and clasper. The genital capsule of $N$. itatiaia has a conspicuous shape, with a posterior rounded protuberance, absent in other species.

\section{New records}

\section{Notonecta disturbata Hungerford, 1926}

Notonecta disturbata is a common species that occurs in Paraguay and Argentina (Moreira et al. 2011), and is also widely distributed in Brazil (see records below). This species shows substantial variation in color, with individuals entirely clear to individuals with most of the body dark and with some clear stains.

It is very similar to $N$. pulchra, with the same range of body length. They are better distinguished by the shape of the genital capsule. Notonecta disturbata has two caudoventral protuberances and the dorsal portion of the genital capsule is acute; $N$. pulchra has only one caudoventral protuberance and the dorsal portion of the genital capsule is rounded.

Known distribution in Brazil. North (Tocantins) (TRUXAL 1957), Central-West (Mato Grosso and Goiás) (Truxal 1957, Nieser 1970), Southeast (Minas Gerais and Rio de Janeiro ${ }^{2}$ ) (Hungerford 1933, Ribeiro et al. 1998, 2010, Melo \& Nieser 2004) and South regions (Rio Grande do Sul) (BACHMANN 1971).

\footnotetext{
${ }^{1}$ HUNGERFoRd (1933) considered N. variabilis virtually identical to $N$. indica Linnaeus, 1771 from Puerto Rico, but he chose to retain the name $N$. variabilis for the specimens from Brazil until there were more specimens available for study. In our key the structural characteristics presented for N. variabilis are, in fact, those from $N$. indica.

${ }^{2}$ Cited as "Campo, Bello Staat, Rio de Janeiro" (HunGerford 1933). The district of Campo Belo was part of the territory of the municipality of Resende, state of Rio de Janeiro. This district was raised to the category of municipality, under the name Itatiaia, in 1988 (IBGE 2009).
} 

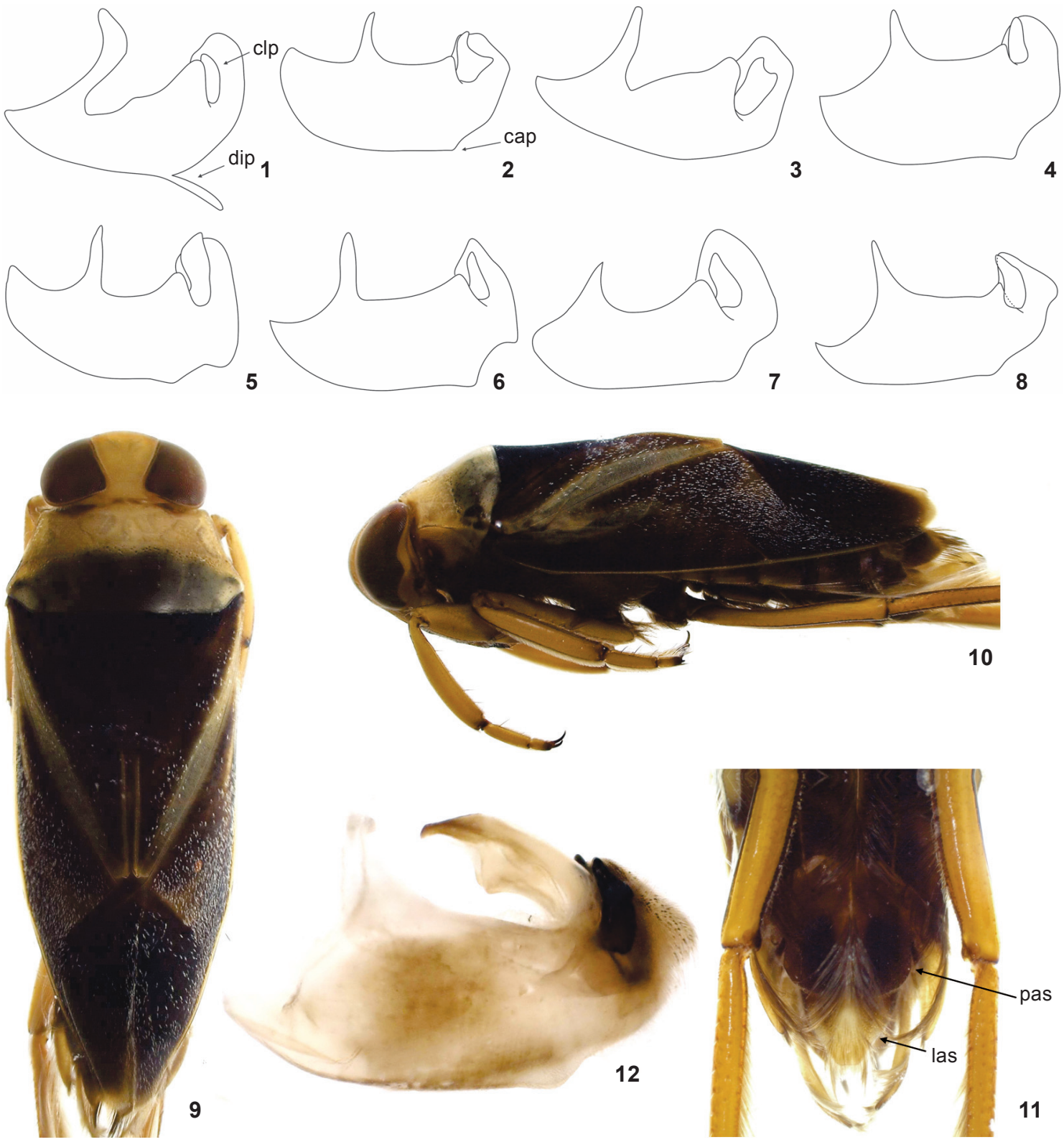

Figures 1-12. (1-8) Genital capsule, lateral view: (1) Notonecta nigra; (2) N. sellata; (3) N. variabilis; (4) N. pulchra; (5) N. polystolisma; (6) N. disturbata; (7) N. bifasciata; (8) N. itatiaia. (9-12) Notonecta itatiaia sp. nov.: (9) habitus, dorsal view; (10) habitus, lateral view; (11) penultimate and last abdominal sternites; (12) genital capsule, lateral view. (cap.) Caudoventral protuberance, (clp.) clasper, (dip.) digitiform process, (pas.) penultimate abdominal sternite, (las.) last abdominal sternite.

Material examined. BRAzIL: state of Pará (!), Parauapebas, FLONA de Carajás, Serra Norte, 09.IX.2006 (N. Ferreira Jr \& L.L. Dumas), det. J.F. Barbosa: $7 \mathrm{f}$ and 8m, macropterous (DZRJ); APA do Igarapé Gelado, Lago Gelado, Cela 7, 22.IX.2007 (N. Ferreira Jr. \& V.P. Alecrim): 1m, macropterous (DZRJ); FLONA de Carajás, N4-D, 21.IX.2007: 1m, macropterous (DZRJ); Canaã dos Carajás, Floresta Nacional de Carajás, Serra Sul, Lagoa S11B-A, 06 20120"S/ $50^{\circ} 23^{\prime} 25^{\prime \prime} \mathrm{W}, 15 . \mathrm{IX} .2006$ (L. L. Dumas \& N. Ferreira Jr.): $1 \mathrm{~m}$ and 2f, macropterous (DZRJ); Lagoa S11D-F (Lagoa do Amendoim), $06^{\circ} 23^{\prime} 56.87^{\prime \prime} \mathrm{S} / 50^{\circ} 22^{\prime} 17.53^{\prime \prime W}, \mathrm{XI} .2012$ (Lab. Limnologia UFRJ): $1 \mathrm{~m}$ and $1 \mathrm{f}$, macropterous (DZRJ); Lagoa S11B-D, 06 $21^{\prime} 8.21^{\prime \prime} \mathrm{S} /$ 50²3'38.13"W, 730 m, XI.2011 (Lab. Limnologia UFRJ): 1m, macropterous (DZRJ); Curionópolis, FLONA de Carajás, Serra Pelada, L.A., 20.IX.2007: 3m and 5f, macropterous (DZRJ); state 
of Piauí (!), Piracuruca, Parque Nacional de Sete Cidades, Cachoeira do Riachão, 0406'28"S/41²40'13"W, 171 m, 09.II.2013 (D.M. Takiya \& A.P.M. Santos): 2m, macropterous (DZRJ); alojamento, 405'57"S/4142'34"W, 193 m, 12.II.2013 (A.P.M. Santos \& D.M. Takiya): $3 \mathrm{~m}$ and 1f, macropterous (DZRJ); state of Minas Gerais, Itamonte, Parque Nacional do Itatiaia, Brejo da Lapa, represa abaixo da cachoeira, 13.IX.1996 (Equipe do Laboratório de Entomologia - UFRJ), det. R.M.C. Paiva: 1m, macropterous (DZRJ); Bocaina de Minas, Vale do Alcantilado, 23.XII.2000 (P.H. Carvalho), det. J.F. Barbosa: 1f, macropterous (DZRJ); state of Rio de Janeiro, Seropédica, poça próximo à EMBRAPA, 16.VI.2003 (A.L. Netto-Ferreira): 1m, macropterous (DZRJ); Magé, Campo dos Escoteiros, fazenda de criação de peixe, 09.XII.2007 (B. Clarkson \& A. Hoffman): 2f, macropterous; state of São Paulo (!), Ubatuba, Parque Estadual da Serra do Mar, Núcleo Picinguaba, brejo, 17.VI.2004 (N. Ferreira Jr): 2m, macropterous (DZRJ); state of Rio Grande do Sul, Chuí, Poça no Km 5,5 da estrada de acesso a Barra do Chuí, 12.IX.1999 (?), 1m, macropterous (DZRJ).

\section{Notonecta pulchra Hungerford, 1926}

Notonecta pulchra occurs in Brazil, Paraguay and Argentina (Moreira et al. 2011). In Brazil it has not been recorded from the Northeast and South regions.

This species has a genital capsule with the apex strongly rounded as that of N. polystolisma, but the clasper of N. pulchra just reaches the apex of genital capsule, whereas the clasper of $N$. polystolisma clearly exceeds the apex.

Known distribution in Brazil. North (Amazonas) (NIESER 1970, Pereira \& Melo 2007, Barbosa \& Rodrigues 2013), CentralWest (Mato Grosso do Sul) (Floriano et al. 2013) and Southeast regions (Minas Gerais and Rio de Janeiro) (Nieser \& Melo 1997, Melo \& Nieser 2004, Ribeiro et al. 2010).

Material examined. BraziL: state of Amazonas, Iranduba, várzea, 07.VII.2008 (J.F. Barbosa), det. J.F. Barbosa: 1m and 1f, macropterous (INPA); Rio Solimões, Lago Janauari, banco de macrófitas e raízes, 11.VII.2008 (J.F. Barbosa): 1m, macropterous (INPA); state of Pará (!), Parauapebas, FLONA de Carajás, A.P.A. do Igarapé Gelado, Lago Gelado, Cela 7, 22.IX.2007 (N. Ferreira Jr. \& V.P. Alecrim): 1m, macropterous (DZRJ); state of Minas Gerais, Manga, ?, col. ?, 1m, macropterous (DZRJ).

\section{Notonecta polystolisma Fieber, 1851}

Notonecta polystolisma occurs in south Brazil and Argentina (Moreira et al. 2011) and is the largest species among the three species cited. It has a general dark facies and genital capsule with two caudoventral protuberances as in $N$. disturbata. They are distinguished by the rounded shape of caudoventral protuberances and the clasper clearly surpassing the apex of the genital capsule in $N$. polystolisma, whereas in N. disturbata the caudoventral protuberances are more acute and the clasper does not exceed the apex of genital capsule.
Known distribution in Brazil. Southeast (Minas Gerais and São Paulo) (Hungerford 1933, Nieser \& Melo 1997, Vianna \& Melo 2003, Souza et al. 2006) and South regions (Paraná and Santa Catarina) (JACZewski 1928, Museo Civico di Rovereto 2012).

Material examined. BrAziL: state of São Paulo, Ubatuba, Parque Estadual da Serra do Mar, Núcleo Picinguaba, brejo, 17.VI.2004 (N. Ferreira Jr), det. J.F. Barbosa: 2m and 1f, macropterous (DZRJ); São José do Barreiro, PARNA Serra da Bocaina, Conde D'Eu, poça, 24.III.2009 (D. B. Provete): 1m and 1f, macropterous (DZRJ); 26.V.2009: $7 \mathrm{~m}$ and 10f, macropterous (DZRJ); 21.VI.2009: $1 \mathrm{~m}$ and 1f, macropterous (DZRJ); 21.VI.2009 (D.B. Provete): $1 \mathrm{~m}$ and $1 \mathrm{f}$, macropterous (DZRJ); paredão, poça, 26.III.2009: 1f, macropterous (DZRJ); base, poça, 11.IV.2009: 1f, macropterous (DZRJ); ponte alta, poça, 18.IV.2009: 1m, macropterous (DZRJ); 25.V.2009: 1m, macropterous (DZRJ); 21.VI.2009: $1 \mathrm{~m}$ and 1f, macropterous (DZRJ); Nascente Éden, 20.IV.2009: 1f, macropterous (DZRJ); Conde D'Eu, poça, IV.2009: 4f, macropterous (DZRJ); 21.IV.2009: 1f, macropterous (DZRJ).

\section{ACKNOWLEDGMENTS}

We are grateful to all collectors who provided specimens examined in this study. This work was sponsored by The Brazilian Council of Scientific and Technological Development (CNPq) and Research Support Foundation of the State of Rio de Janeiro (FAPERJ).

\section{LITERATURE CITED}

Bachmann, A.O. 1971. Catalogo sistematico y clave para la determinación de las subfamilias, géneros y especies de las Notonectidae de la Republica Argentina. Physis 30: 601-617.

Barbosa, J.F. \& H.D.D. Rodrigues. 2013. A new species of Martarega White, 1879, with new distributional records of Notonectidae (Hemiptera: Heteroptera: Nepomorpha) from Brazil. Zootaxa 3682 (4): 534-540.

Floriano, C.F.B.; I.A.D.V. Oliveira \& A.L. Melo. 2013. New records and checklist of aquatic and semi-aquatic Heteroptera (Insecta: Hemiptera: Gerromorpha and Nepomorpha) from the Southern region of Mato Grosso do Sul, Brazil. Biota Neotropica 13 (1): 210-219.

Hungerford, H.B. 1933. The genus Notonecta of the world (Notonectidae-Hemiptera). The University of Kansas Science Bulletin 21 (1): 1-195.

IBGE. 2009. Documentação territorial do Brasil. Instituto Brasileiro de Geografia e Estatística. Available online at: http://biblioteca.ibge.gov.br [Accessed: 04.V.2009]

JaCzewski, T. 1928. Notonectidae from the State of Paraná. Prace Panstwowego Muzeum Zoologicznego 7: 121-136.

López Ruf, M. L.; S.A. Mazzucconi \& A.O. Bachmann. 2003. Heteróptera acuáticos y Semiacuáticos del Parque Nacional Mburucuyá (Provincia de Corrientes, Argentina). Revista de la Sociedad Entomológica Argentina 62 (1-2): 65-71. 
Melo, A.L. \& N. Nieser. 2004. Faunistical notes on aquatic and semiaquatic Heteroptera of Minas Gerais (Brazil): an annotated list of Gerromorpha and Nepomorpha collected near Januária. Lundiana 5: 43-49.

Moreira, F.F.F.; J.F. Barbosa; J.R.I. Ribeiro \& V.P. Alecrim. 2011. Checklist and distribution of semiaquatic and aquatic Heteroptera (Gerromorpha and Nepomorpha) occurring in Brazil. Zootaxa 2958: 1-74.

Museo Civico di Rovereto. 2012. Patrimonio Online e WebGis. Available online at: http://www.museocivico.rovereto.tn.it [Accessed: 17.XII.2012].

Nieser, N. 1970. Records of South American Notonectidae mainly from the Amazon-Region. Studies on the Fauna of Suriname and other Guyanas 12: 71-93.

Nieser, N. \& A.L. Melo. 1997. Os heterópteros aquáticos de Minas Gerais. Guia introdutório com chave de identificação para as espécies de Nepomorpha e Gerromorpha. Belo Horizonte, Editora Universidade Federal de Minas Gerais, 180p.

Pereira, D.L.V. \& A.L. Melo. 2007. Aquatic and semiaquatic Heteroptera (Insecta) from Pitinga, Amazonas, Brazil. Acta Amazonica 37: 643-648.

Ribeiro, J.R.I.; J.L. Nessimian \& E.C. Mendonça. 1998. Aspectos da distribuição dos Nepomorpha (Hemiptera: Heteroptera) em corpos d'água na Restinga de Maricá, Estado do Rio de
Janeiro, p. 113-128. In: J.L. Nessimian \& A.L. Carvalho (Eds). Ecologia de Insetos Aquáticos. Rio de Janeiro, PPGE-UFRJ, Series Oecologia Brasiliensis, vol. 5, XVII+310p.

Ribeiro, J.R.I.; F.F.F. Moreira; V.P. Alecrim; J.F. Barbosa \& J.L. Nessimian. 2010. Espécies de heterópteros dulciaquícolas (Hemiptera, Heteroptera, Gerromorpha e Nepomorpha) registradas no Estado do Rio de Janeiro. Arquivos do Museu Nacional 67 (3-4): 303-312.

SouzA, M.A.A.; A.L. Melo \& G.J.C. Vianna. 2006. Heterópteros aquáticos oriundos do Município de Mariana, MG. Neotropical Entomology 35 (6): 803-810.

ŠTYS, P. \& A. JANSSON. 1988. Check-list of recent family-group and genus-group names of Nepomorpha (Heteroptera) of the world. Acta Entomologica Fennica 50: 1-4.

Truxal, F.S. 1957. The Machris Brazilian Expedition. Entomology: general systematics of the Notonectidae (Hemiptera). Contributions in Science 12: 3-23.

TRuxAL, F.S. 1979. Family Notonectidae-Backswimmers, p. 139147. In: A.S. Menke (Ed.). The semiaquatic and aquatic Hemiptera of California (Heteroptera: Hemiptera). Bulletin of the California Insect Survey 21: 1-166.

Vianna, G.J.C. \& A.L. Melo. 2003. Distribution patterns of aquatic and semi-aquatic Heteroptera in Retiro das Pedras, Brumadinho, Minas Gerais, Brazil. Lundiana 4: 125-128.

Submitted: 04.VI.2013; Accepted: 24.VIII.2013.

Editorial responsibility: Gabriel L.F. Mejdalani 